\title{
ANTS AS ECOSYSTEM ENGINEERS IN NATURAL RESTORATION OF HUMAN MADE HABITATS
}

\author{
PAVEL KovÁŘ ${ }^{1}$, PAVEL VoJTíšEK ${ }^{2} \&$ IRENA ZENTSOVÁ ${ }^{2}$
}

\author{
${ }^{I}$ Department of Botany \& ${ }^{2}$ Institute of the Environment, Faculty of Science, Charles \\ University in Prague, Benátská 2, 12801 Prague 2, Czech Republic
}

Received: $\mathbf{1 5}^{\text {th }}$ May 2013, Accepted: $17^{\text {th }}$ July 2013

\begin{abstract}
Three to four dominant seed-transporting ant species of different size categories (Tetramorium caespitum, Lasius niger, Formica rufibarbis/Formica pratensis) on the plateau of abandoned ore sedimentation basin (tailings containment) were studied as pioneer and subsequent colonisers of this industrial waste deposit, from the viewpoint of their functioning in plant seed dispersal. We examined the role of ants in primary vegetation succession. Experiments of seed removal by ants with plant species found within close proximity of tailings were related to the succession. Ant activity generates a considerable shift in the quality of the colonised surface, as they collectively act as ecosystem engineers.
\end{abstract}

Keywords: human-made habitats, industrial-waste deposits, abandoned tailings containment, primary vegetation succession, plant species diversity, dispersal of plant seeds, ant-plant interaction, myrmecochory, ecosystem engineers, bioturbation

\section{INTRODUCTION}

Ants often play an important role in the dynamics of plant communities acting as seed dispersal agents (e.g. Hölldobler et Wilson 1990, Jolivet 1996, Kovář et Kovářová 1998). Foraging workers are likely to take seeds as food into their nests, carrying them a distance away from the parent plant. Although ants disperse seeds over relatively short distances, advantages commonly associated with this dispersal strategy include avoidance of parent competition and of density-dependent predation, as well as dispersal towards microsites favorable to germination (Wolf et Debussche 1999, Kovár et al. 2001). Activity of successionally alternating ant species during decades imply significant change of the substrate by bioturbation during nest-building (Dostál et al. 2005, Frouz et Jílková 2008) and dynamics in vegetation development (Vlasáková et al. 2009, Vojtíšek 2012). To build and maintain mounds, ants transport large amounts of substrate from deeper layers (King 1981, Frouz 1996), through a process known as bioturbation (e.g., Meysman et al. 2006). As a result, ants influence concentrations of chemical elements, soil texture, amount of soil organic matter, activity and biomass of microfauna, $\mathrm{pH}$ as well as the other soil properties (Czerwinski et al. 1971, Culver et al. 1983, Frouz et al. 1997). This phenomenon, which reflects physical and chemical effects of the soil biota's microdisturbations such as anthills or molehills - having a positive effect on vegetation succession - is usually summarised in 
the term ecosystem engineering (e.g., Jones 1994, Wright et Jones 2004, Jouquet et al. 2006, Sanders et van Veen 2011). It is apparently functional on spoil substrates enriched in heavy metals - in abandoned tailings of our interest, too, where adjacent processes of the soil improvement are facilitated in this way (Kovář 2004, Kovář et al. 2011, Štefánek et al. 2012).

\section{Aim of the study}

The main aim of the study is to compare plant cover on the tailings containment and the influence of the ant activity on dispersal of plants, and facilitation of primary succession of vegetation after approximately 10 years of spontaneous development. Periods of comparison: the first one in 1998-2000 (sparse mosaic of lichens, herbs and shrubs; Jarešová et Kovář 2004) and the second one in 2011-2012 (differentiated mosaic including tree stands; Vojtíšek 2012).

\section{Study site}

An abandoned sedimentation basin with ore deposits is located on the left bank of the Elbe river, close to the old surface quarry near Chvaletice in the northern part of Železné hory hills, Czech Republic. Geographical location: $50^{\circ} 02^{\prime} \mathrm{N}, 15^{\circ} 26^{\prime} \mathrm{E}$; altitude $200 \mathrm{~m}$. Area under spontaneous natural restoration: 40 ha. Habitat parameters: Waste sludge of Fe-Mn ores with high sulphur and phenol contents were hydraulically transferred and deposited in tailings containment (abandoned gradually in 1975-1980). The non-reclaimed basin has remained largely treeless or non-vegetated and no manipulations were carried out after abandonment (across the total surface area in 1984).

\section{METHODS}

\section{Series of vegetation succession (in 1998 and 2011)}

Physiognomically distinct vegetational types correlating with successional stages were selected: (1) in 1998 - (a) mosaic of open areas with sporadic vegetation of mosses, lichens and herbs, almost predominantly with the grass Calamagrostis epigejos), (b) mosaic of herb stands with seedlings and saplings of aspen (Populus tremula) and birch (Betula pendula), and (c) relatively tall (max. $3 \mathrm{~m}$ ) stand of birch and aspen; (2) in 2011 - (A) open space with cryptogams, (B) herb stand (grassland), (C) shrubby stand (seedlings of Betula pendula, Populus tremula, Salix sp. div., Pinus sylvestris, Tilia platyphyllos, Cerassus avium, Sarothamnus scoparius), and (D) the most developed community with trees, mainly birch (Betula pendula) and aspen (Populus tremula), about $5 \mathrm{~m}$ tall. Phytocoenological relevés in plant stands were recorded using seven-grade scale of abundance (Braun-Blanquet 1928). The results of this analysis in more detailed description were published in the previous study (Kovár et al. 2011).

\section{Frequency of ant nests in different plant stands}

Dominant ant species were studied in the surface plateau of the abandoned sedimentation basin: Tetramorium caespitum (Linnaeus, 1758); Lasius niger (Linnaeus, 1758), and Formica rufibarbis (Fabricius, 1793) - in 1998-2000; the last one was partly substituted by Formica pratensis (Retzius, 1783) - in 2011. Each of these species represents a different size category - Tetramorium being the smallest, Lasius being medium-sized, and Formica the largest. Inside above-mentioned successional formations, 10 × $10 \mathrm{~m}$ quadrats were 
randomly set, three in each vegetation type. The plots were fixed and marked, closely prospected and every location of ant nest was recorded.

\section{Ants and seed removal experiments}

Ant activity supporting dispersal of plants and facilitating primary succession of vegetation was studied with the help of repeated seed removal experiments (after the period of approximately 10 years). Seeds were offered in especially constructed two-layer round dishes, protecting seeds from other predators and from rain and the wind. The base of each dish had a low edge to avoid problems with access, even by the smallest ant Tetramorium caespitum. As the subject of this testing was only attractiveness of the seeds, not the distance of their dispersal, seeds were exposed next to ant nests. In a growing season, seeds were always offered from June until September when seeds were mature. The length of exposure was eight hours (10.00 a.m. - 6.00 p.m.). Seeds of 20 plant species (1998-2000) and more (2011-2012) collected around the ore deposits (just as they ripened) were used for this experiment. In both periods, three size categories of dominant ants were tested in seed removal experiments: (1) 1998-2000: Tetramorium caespitum, Lasius niger, Formica rufibarbis, (2) 2011-2012: Tetramorium caespitum, Lasius niger, Formica pratensis. Succession of ant species over ten years produced a two-fold increase in their diversity (when Formica sanguinea and $F$. pratensis represent semi-parasitic species using the nest occupation of the pioneers Formica cunicularia or F. rufibarbis.

Table 1: Parameters of particular plant species used in offer experiments (1998-2000)

\begin{tabular}{|c|c|c|c|c|}
\hline Species & $\begin{array}{c}\text { Life } \\
\text { Form }\end{array}$ & Length of life & Type of distribution & Family \\
\hline Acetosella vulgaris & Th & A & ANIMa & Pgo \\
\hline Agrostis tenuis & $\mathrm{H}$ & $\mathrm{P}$ & ANIMa+WIND & Gra \\
\hline Anthoxanthum odoratum & $\mathrm{H}$ & $\mathrm{P}$ & ANIMa & Gra \\
\hline Carex vulpina & $\mathrm{H}$ & $\mathrm{P}$ & ANIMa & Cyp \\
\hline Cerastium vulgatum & $\mathrm{H}$ & $\mathrm{P}$ & UNSP & Car \\
\hline Holcus lanatus & $\mathrm{H}$ & $\mathrm{P}$ & UNSP & Gra \\
\hline Hypericum perforatum & $\mathrm{H}$ & $\mathrm{P}$ & WIND & Hyp \\
\hline Chrysanthemum leucanthemum & $\mathrm{H}$ & $\mathrm{P}$ & UNSP & Com \\
\hline Lotus corniculatus & $\mathrm{H}$ & $\mathrm{P}$ & UNSP & Leg \\
\hline Luzula multiflora & $\mathrm{H}$ & $\mathrm{P}$ & ANIMe & Jce \\
\hline Lychnis flos-cuculi & $\mathrm{H}$ & $\mathrm{P}$ & WINDc & Car \\
\hline Plantago lanceolata & $\mathrm{H}$ & $\mathrm{P}$ & ANIMm & Pla \\
\hline Poa pratensis & $\mathrm{H}$ & $\mathrm{P}$ & UNSPag+WIND & Gra \\
\hline Potentilla argentea & $\mathrm{H}$ & $\mathrm{P}$ & UNSP & Ros \\
\hline Rumex obtusifolius & $\mathrm{H}$ & $\mathrm{P}$ & ANIMa & Pgo \\
\hline Trifolium dubium & Th & A & ANIMa & Leg \\
\hline Tripleurospermum inodorum & Th & A & UNSP & Com \\
\hline Vicia hirsuta & Th & A & UNSP+ANIM & Leg \\
\hline Vicia sativa & Th & A & UNSP+ANIM & Leg \\
\hline Vicia tetrasperma & Th & $\mathrm{A}$ & UNSP & Leg \\
\hline
\end{tabular}

Life form: $\mathbf{H}$ - hemicryptophyte, Th - therophyte. Length of life: $\mathbf{P}$ - perennials, A - annuals. Distribution: UNSP non-specified, ANIMe - zoochory, presence of elaiosome, ANIMa - epi-zoochory (hair, feathers), ANIMm - epizooochory (sticky secretions). WIND - anemochory. Plant family: Pgo - Polygonaceae, Gra - Gramineae, Cyp Cyperaceae, Car - Caryophyllaceae, Hyp - Hypericaceae, Com - Compositae, Leg - Leguminosae, Jce - Juncaceae, Pla - Plantaginaceae, Ros-Rosaceae. According to Grime et al. (1988), and the last author's observation. 


\section{Species diversity and effectiveness of myrmecochory}

Species-area curves were constructed (2012) for plants by extending the sampling area and counting the present plant species in each doubled quadrat (all this in four repetitions on the (1) area with ant nests, and (2) area without ant nests of the abandoned tailings containment. The potential argument is that differences in plant species diversity, observed within both areas within the deposit plateau, were not primarily caused by presence/absence of ant nests. Instead, these differences were attributed to different microhabitat conditions that evolved the following transplantation control. Five plots $15 \times 15 \mathrm{~cm}$ were placed randomly in the area with an absence of ant nests, and the seeds of six relatively common plant species in many places on the deposit were sown in them: Holcus lanatus, Vicia hirsuta, Plantago lanceolata, Agrostis tenuis, Trifolium repens, Rumex acetosella. Their seedlings were monitored during the growing season (2012).

\section{Substrate properties}

Six soil samples were taken from each of three layers $(0-2 \mathrm{~cm}, 2-4 \mathrm{~cm}$, and $4-8 \mathrm{~cm}$, respectively). The following characteristis of the substrate were analysed: incinerable $\mathrm{C}$, available $\mathrm{P}, \mathrm{pH}$ and conductivity (measure of salinity) within all 4 vegetation types and/or habitats (see above). All analytical procedures used were the same, and comparable with previous studies in the locality (Kováŕ 2004; in details Vojtíšek 2012).

\section{RESULTS}

\section{Ant species and ecological succession}

Successional shift from three very weakly-defined clusters of vegetation in 1998 consisted of four relatively well differentiated types of habitats in 2012 (see Methods). Results of the earlier term within the vegetation succession (Jarešová et Kovár 2004) showed that lichen and moss species together with the annuals Vicia tetrasperma and V. hirsuta occupy one semi-open environment. In contrast, woody species and other vascular plants (Calamagrostis epigejos, Phragmites australis) represent the most advanced type of plant stand.

It is possible to conclude that differences among vegetation relevés relate to vegetation coverage. Since all three ant species studied in the period 1998-2000, namely Formica rufibarbis, indicate their preference to occupy habitat mosaics with open surfaces. However, the mutual relationship between ants and plants does not show significant dependencies between an ant species and a particular plant species. Tetramorium caespitum and Formica rufibarbis are closely associated with the presence of herbs, mostly of Vicia species, and Calamagrostis epigejos. From nest numbers listed in Table 2, it is apparent that Lasius niger is the most widespread ant of all the species in this locality. This species builds its nests mostly in places with low growth of aspen and birch seedlings and saplings. Tetramorium caespitum and Formica rufibarbis prefer surfaces with sparse vegetation.

The pattern of nests belonging to the aforementioned ant species during the 2011-2012 survey period, confirms the previous knowledge about their dependence on habitat and/or vegetation types. An increasing proportion of tall woody stands slightly supressed typically pioneer ant colonisers such as Formica rufibarbis or F. cunicularia. These species probably became the target of attacks from successionally advanced species (Formica sanguinea, F.pratensis) known as semi-parasitic invaders to a suitable phase of the ecosystem development. This was the reason why attention was paid to behaviour of newly established nests of Formica pratensis, apparently bound with periodic shadow by tree coverage and/or 
relatively dense vegetation. Intraspecific competition among nests of this Formica species probably caused the success of the one nest (ant hill) with very high numbers of individuals and wide territorial range of activity (tens of metres). However, it is relatively weak at competing with the other size categories of ants (Tetramorium caespitum, Lasius niger). Namely Lasius niger seems to be highly mobile with the construction of new nests in this industrial environment, and it exhibits a ruderal-type adaptive strategy in diverse microbahitat mosaics. A total of 12 ant species were identified within the locality: Formica cunicularia, F. rufibarbis, F. cinerea, F. sanguinea, $\underline{F}$. pratensis, Lasius niger, L. flavus, $\underline{L}$. platythorax, Myrmica schencki, M. rubra, Tetramorium caespitum, Temnothorax crassipinus (underlined names indicate the species recorded in 2012 against the year 1998).

Table 2: Average numbers of ant nests per quadrat $\left(10 \times 10 \mathrm{~m}^{2}\right)$ related to vegetation types: 1 - mosaic of open surface with cryptogams and sparse herb vegetation, 2 - mosaic of herb stands, and seedlings or saplings of aspen and birch, 3 - woody stands with taller growth of aspen and birch.

\begin{tabular}{||c|c|c|c||}
\hline $\begin{array}{c}\text { Vegetation } \\
\text { type }\end{array}$ & $\begin{array}{c}\text { Tetramorium } \\
\text { caespitum }\end{array}$ & $\begin{array}{c}\text { Lasius } \\
\text { niger }\end{array}$ & $\begin{array}{c}\text { Formica } \\
\text { rufibarbis }\end{array}$ \\
\hline 1 & 5,00 & 4,67 & 1,33 \\
2 & 4,33 & 8,67 & 0,00 \\
3 & 4,33 & 7,00 & 0,00 \\
total & 13,67 & 20,33 & 1,33 \\
\hline
\end{tabular}

Assessment of variability in plant species richness on the abandoned sedimentation basins (Vaňková et Kovár 2004) demonstrated high heterogeneity of especially the orewashery deposits - such as in Chvaletice. Relatively distinct groups of plant taxa associated with either the ash-slag or ore-washery deposits were distinguished. However, there are numerous groups of species of wider ecological amplitude lacking a strict connection to the type of industrial sediments (the bodies of deposits represent early stages of succession and/or persist in early stages of succession for a long time). Transport of diaspores from the surrounding landscape, mainly through zoochory and anemochory, is among the factors governing the development of plant communities in the initial and/or young stages of succession (Kováŕ 2004).

A typical S-shape in species-area curves was observed when number of plant species plotted against increasing plots was demonstrated for the tailings surface (Fig. 1). However, the steepness of the curve was considerably greater in the area colonised by the ant nests, in comparison to the area without the ant nests and/or with only their sporadic incidence (the highest number of nests in the frame of four quadrats $10 \times 10 \mathrm{~m}$ monitoring was 30 in the first case, and 9 in the second one). Low numbers of plant species were found in the interior part of the abandoned sedimentation plateau in 1998 (less than 10), while in 2012 numbers were approximately four-times higher. A similar relationship is observed for the areas with extremely rare presence of ant nests in comparison with dense incidence of ant nests (Fig. 1). 
Fig. 1: Species-area relationsips on the abandoned sedimentation basin in Chvaletice, in the surface plateau area with only rare occurrence of ant nests (left) and in the surface plateau area with high density of ant nests (right) - data from 2011.
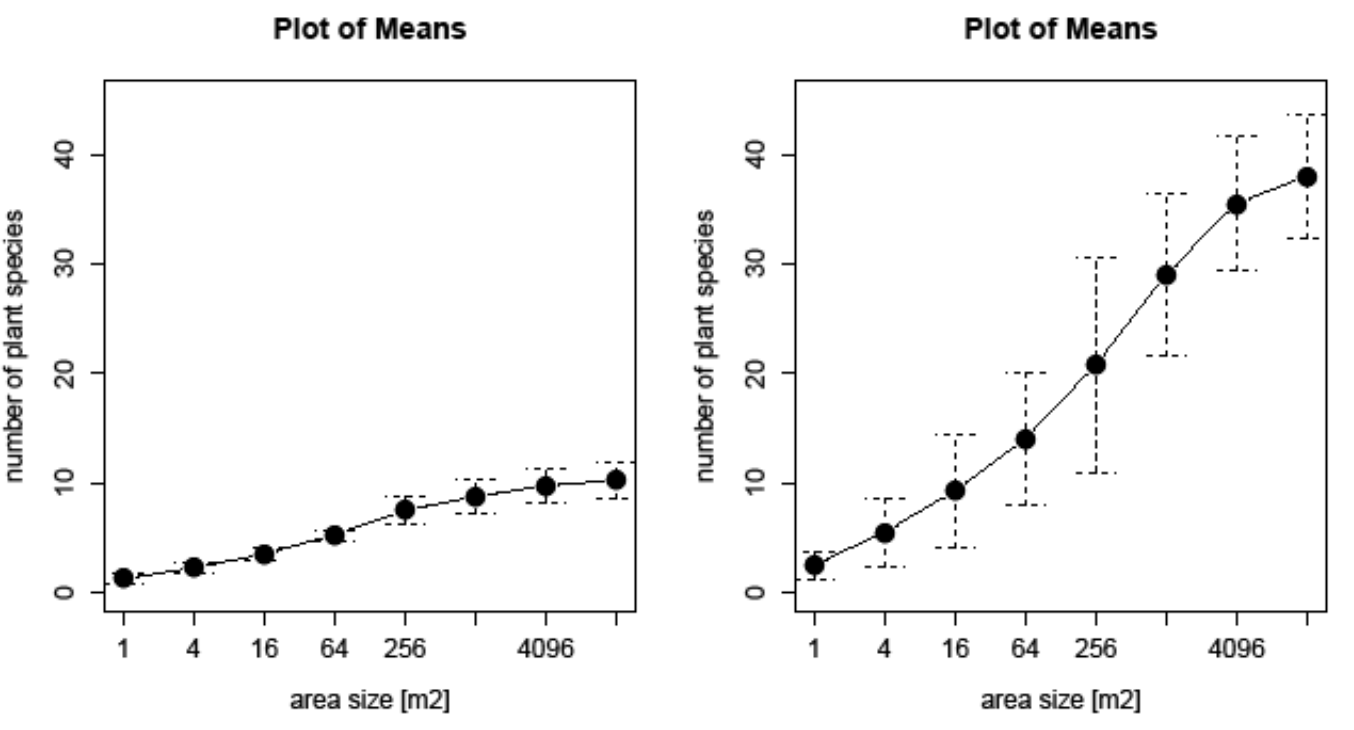

\section{Experiments with removal and transportation of seeds by ants}

Data from experiments with seed offered to particular ant colonies (1998-2000, Table 1) were processed with the help of ANOVA. First, the species specific differences in seeds collecting were tested, including test of significant differences. According to Tukey test, Lasius niger showed the highest seed dispersal of the three ant species. However, there was no significant difference in seed dispersal between Formica rufibarbis and Tetramorium caespitum (Fig. 2). Figure 3 shows a different trend of seed collecting by Lasius niger during the growing season (1999) compared with the two other ant species. Analogical comparison at the same abandoned tailings containment 12 years later (Tetramorium caespitum, Lasius niger,Formica pratensis) shows dominance in the seed dispersal activity of the largest size category of ant species (Fig. 4). In the first case (Fig. 2) Lasius niger dominates in gathering of seeds, in the second one (Fig. 4) Formica pratensis is the most active species in the seed collection process (Table 3 ). In general, the results showed significant differences in seed dispersal of several plant species related to collecting effectiveness of ants.Ant workers of a particular species preferred certain plant species (Jarešová et Kovár 2004). For example, Chrysanthemum leucanthemum was more preferred than other plant species. In comparison, Hypericum perforatum and Vicia sativa were collected in very small amounts. 
Table 3: Two groups of plant seeds for experimental offering to ants according to seasonal period (first group harvested in the second half of June and the first half of July left, second group harvested in the second half of July and the first half of August), 20112012.

\begin{tabular}{|c|c|}
\hline First group of seeds for offer & Second group of seeds for offer \\
\hline Potentila argentea (Po.Arg) & Holcus lanatus (Ho.Lan.) \\
\hline Rumex acetosella (Ru.Act) & Hieracium laevigatum (Hie.Lae.) \\
\hline Holcus lanatus (Ho.Lan.) & Plantago lanceolata (Pla.Lanc.) \\
\hline Calamagrostis epigejos (Cal.Ep) & Trifolium arvense (Tri.Arv.) \\
\hline Trifolium dubium (Tri.Dub) & Calamagrostis epigejos (Cal.Ep.) \\
\hline Poa pratensis (Poa) & Melilotus officinalis (Mel.Off.) \\
\hline Trifolium repens (Tri.Rep.) & Senecio jacobaea (Sen.Jac.) \\
\hline Vicia hirsuta (Vic.Hirs.) & Lotus corniculatus (Lot.Cor.) \\
\hline Agrostis tenuis (Agr.Ten.) & Picris hieracioides (Pi.Hie.) \\
\hline Plantago lanceolata (Pla.Lanc.) & Trifolium repens (Tri.Rep.) \\
\hline \multirow[t]{4}{*}{ Lychnis flos-cuculi (Lich.F.C.) } & Vicia cracca (Vic.Cra.) \\
\hline & Lathyrus tuberosus (Lat.Tub.) \\
\hline & Cirsium arvense (Cir.Arv.) \\
\hline & Centaurium erythraea (Ce.Ery.) \\
\hline
\end{tabular}

Fig. 2: Comparison of average numbers of effective seed collecting by three ant species from arranged offers (the graph includes all data from the growing seasons 1998-2000).

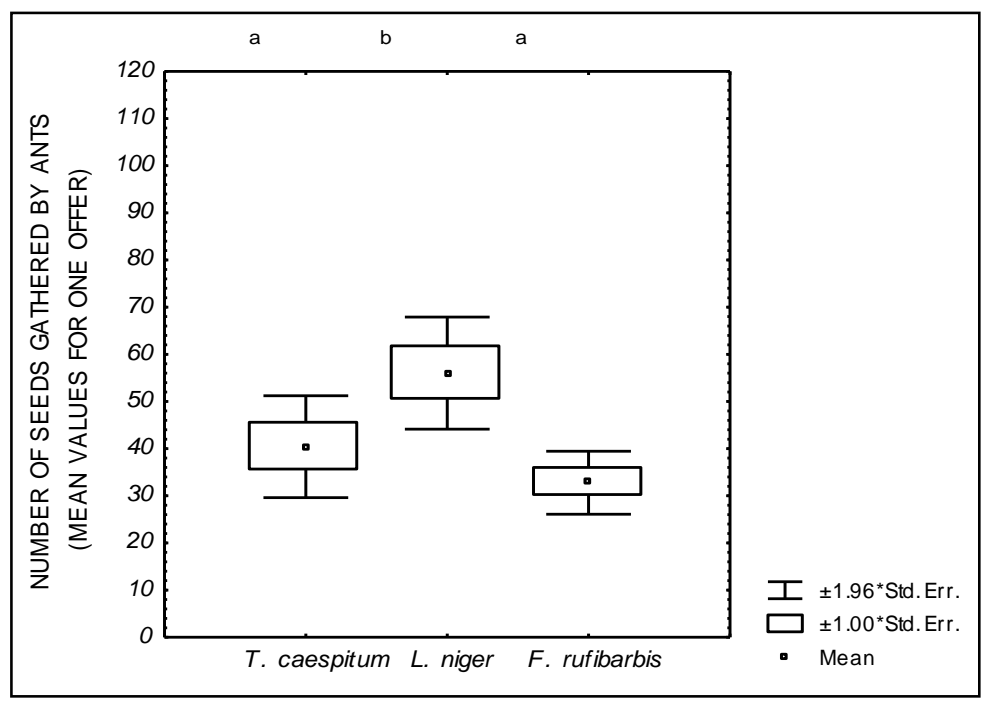


Fig. 3: Box plots show average values of seed collecting by a particular ant species during 4 months of a season (data from 1999).

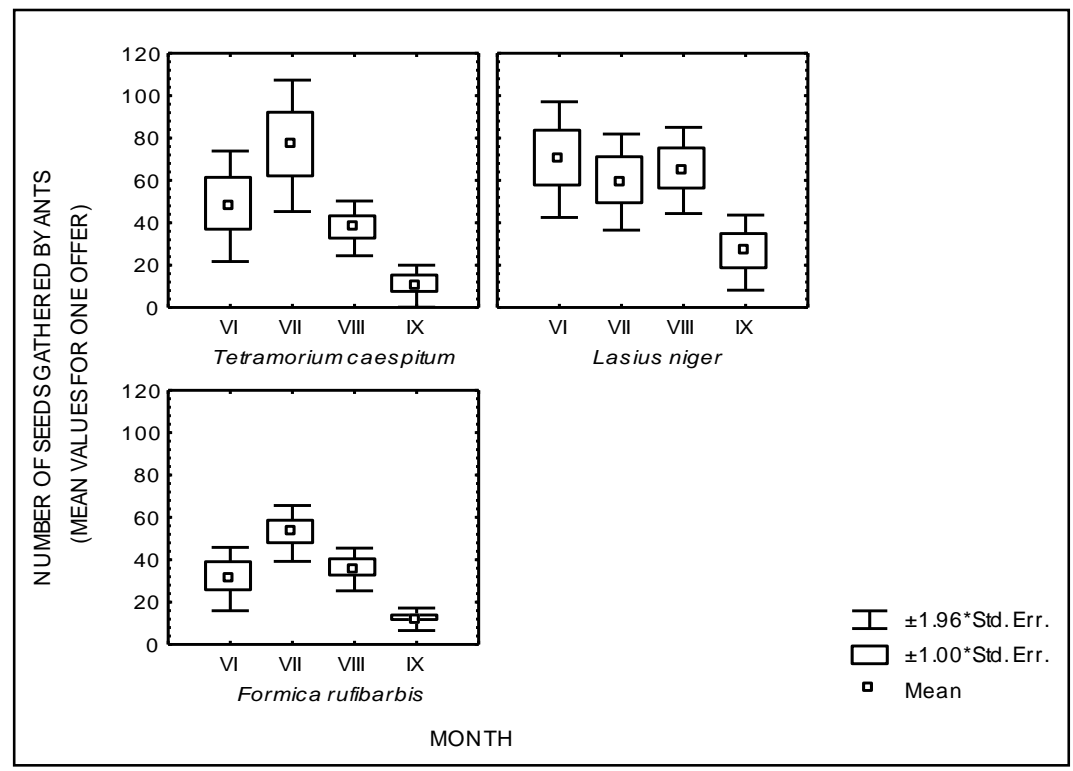

Fig. 4: Comparison of average numbers of effective seed collecting by three ant species ( $\mathrm{F}$ - Formica pratensis, $\mathrm{L}$ - Lasius niger, $\mathrm{T}$ - Tetramorium caespitum) from arranged offers (2011-2012).

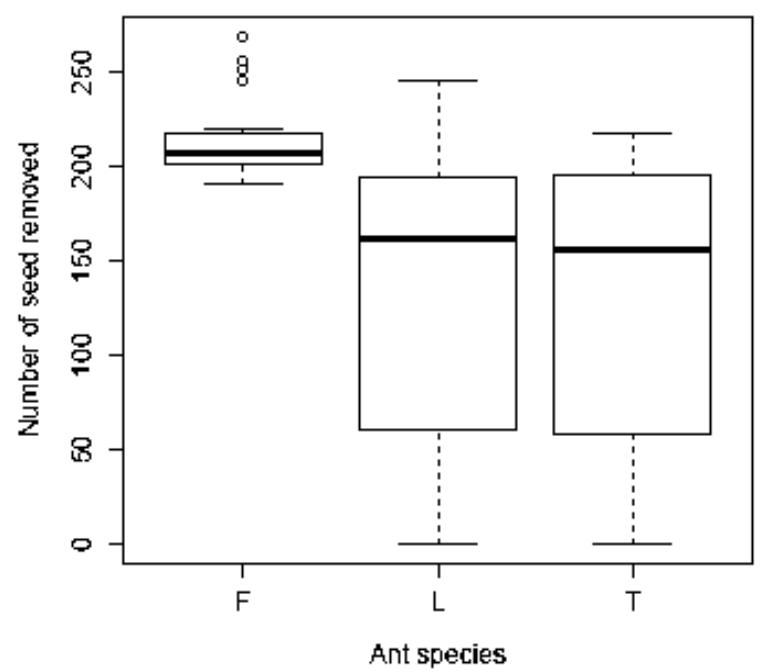

Major behavioral similarity is noticeable between the ant species Tetramorium caespitum and Formica rufibarbis, despite the great difference in their body size: both of them mostly collected large diaspores of Luzula multiflora and Carex vulpina. Another major collecting activity was noted for these two species with respect to seeds of Anthoxanthum odoratum 
and Potentilla argentea. Lasius niger mostly collected Anthoxanthum odoratum and $P$. argentea, followed by Trifolium dubium and Vicia hirsuta. For generalisation of these results, we must to take into account that dispersal of plant diaspores can be, to a certain extent, affected by the season when the seeds were offered.

\section{Substrate properties}

In general, basic substrate properties of studied deposits in Chvaletice are a long-term outcome of the process of sulphidic mineralization which was described by Rauch (2004).

More ecotoxicological aspects in the locality is treated in wider publication (Kovár 2004). Sampling of the substrate covered all 4 types of habitats distinguished for the purposes of studying ant-plant interactions in the abandoned tailings containment during period of 2011-2012: open space with cryptogams (A), herb stand (B), shrubby stand (C) and the most developed community with trees (D). Six soil samplings were taken from each of the three layers $(0-2 \mathrm{~cm}, 2-4 \mathrm{~cm}$, and $4-8 \mathrm{~cm}$, respectively). The following characteristis of the substrate were analysed: incinerable $\mathrm{C}$, available $\mathrm{P}, \mathrm{pH}$ and conductivity (measure of salinity). A very rough illustration of the extent of the above-mentioned variables, which could result in significant obstacles for the continuity of the ant colonisation of the substrate, is shown in Table 4.

Table 4: Scheme of pairs of habitat types on the surface of tailing containment in Chvaletice which significantly differ in a particular soil feature: open space with cryptogams (A), herb stand (B), shrubby stand (C) and the most developed community with trees

(D).

\begin{tabular}{|l|l|l|l|}
\hline & \multicolumn{3}{c|}{ Depth of soil profile } \\
\hline & $0-2 c m$ & $\mathbf{2 - 4} \mathbf{c m}$ & $\mathbf{4 - 8 c m}$ \\
\hline Substrate parameter & & & \\
\hline Carbon & & & \\
\hline & AD & & \\
\hline & CD & & \\
\hline & & & \\
\hline Phosphorus & & & \\
\hline & AB & AD & CD \\
\hline & BC & & \\
\hline & & & \\
\hline Salinity & & & \\
\hline & AB & AB & \\
\hline & AD & AD & AD \\
\hline & BC & BC & \\
\hline & CD & CD & CD \\
\hline & & & \\
\hline pH & & & \\
\hline & & AB & AB \\
\hline & AD & AD & AD \\
\hline & & BC & \\
\hline & CD & CD & \\
\hline
\end{tabular}




\section{DISCUSSION}

Density of occurrence of ant nests within habitats and/or vegetation types, on the abandoned plateau of the ore washery sedimentation basin, shows a relatively high degree of dependence of ant species on vegetation cover in comparison with a particular plant species. The most widespread ant species Lasius niger distributes its colony on places sparsely overgrown by juvenile shrubs and trees. A similar observation was published by Frouz (1996), who monitored occurrence of this species on dumps formed during brown coal mining in the Sokolov region (western Bohemia, Czech Republic). Under environmental conditions comparable with those described in this work, Lasius niger was also a dominant species. It reached the highest values of abundance and biomass in the initial stages of vegetation succession on dumps covered with shrub or herb vegetation. However, on the ore deposit, Lasius niger tended to avoid surfaces overgrown by only herb vegetation - evidently due to extremely high temperatures on the barren ore deposit surface $\left(60^{\circ} \mathrm{C}\right)$. The moss and lichen layer occurring in the successional stage with tree seedlings represents a compact but dynamic cover of the soil surface (Pohlová 2004, Hroudová et Zákravský 2004). The cover which is overheated in sunny days protects the soil below. The space between the compact substrate and the surface layer offers eligible interface shelter for ant migration and food transport including plant diaspores. In experiments with Lasius niger (Brian et al., 1965), this ant survived on very dry soils only if adequate shade was provided. It is ppossible that aspen and birch growing on ore deposits fulfil this function. The two remaining ant species (Tetramorium caespitum and Formica rufibarbis) resisted desiccation more than Lasius niger. This tolerance could explain higher occurrence of those two ant species in areas with sparse vegetation.

In general, Lasius niger was the most successful ant species in myrmecochorous dispersal of plants on the surface of the ore deposit. In comparison, in heathlands of southern England, Tetramorium caespitum exhibited the greatest interest in seeds (Brian 1964). Lasius niger showed a stronger preference to aphid honeydew than other ant species. The most efficient seed collecting ant in a semi-natural ecosystem of mountain pasture was also Tetramorium caespitum, one of 12 ant species present in this ecosystem (Kovár et Kováŕová 1998). However, seedlings of Vicia tetrasperma or Vicia hirsuta were observed relatively frequently under the installed shelters covering the open substrate of the ore deposit, which ants inhabited with their colonies - both the Vicia species were included in seed offer experiments, and consequences of myrmecochory of this type are described in numerous papers (e.g., Wilson 1971, Hölldobler et Wilson 1990, Jolivet 1996, Agosti et al. 2000). Preference of this ant to a specific plant's seeds could explain the onset of these annual Vicia's following fire in August 1994 (Štefánek 2004).

Brian et al. (1967) also noted higher activity of ants in seed collecting in June and July, compared to August and September. It is explained by increased dietary requirements due to nurturing big larvae of sexual individuals in these months. These findings are similar to our results obtained from the abandoned ore deposit in Chvaletice. The increase was significant only in July (together with Tetramorium caespitum), but increased seed dispersal was also exhibited by other species. Major differences between the months might have been suppressed by low offer of insect feed in this generally poor biotope on ore deposit, resulting in greater seed collecting activity throughout the year. Another explanation is that seeds also serve as construction material for ant nests (lack of typical soil, humus and litter with dead plant material are among the limiting factors). This use of seeds is mentioned by a number of authors (Gorb et Gorb 1995, Gorb et Gorb 2000, Gorb et al. 1997). Functioning as a vector of organic litter transport, the ants play a very important 
role in balancing extremity of this environment (overheating of the soil surface, high concentration of heavy metals in the substrate, salinisation etc.), improving the substrate conditions and supporting life and/or successional restoration of the habitat (Agosti et al. 2000).

Differentiation of the areas on deposit surface plateau into parts (1) poor in presence of ant nests and (2) rich in density of ants and their nests - correlated with plant species diversity ( 1 - low, 2 - high) - leads to the question: What is primary? Is is enviroment unfriendly for establishment of plant seedlings, or does the problem consist of poor availability and/or dispersal of seeds by myrmecochory? The transplantation experiment with sowing the seeds of the most common plant species extensively spread throughout the deposit plateau, rather supported the second hypothesis. Germination success of seeds (previously tested for germination ability in laboratory conditions) on that part of deposit with and/or without rare ant nests, confirmed the capacity of local microhabitats to facilitate the growth of plants (Table 5). It is apparent that very weak success in germination is exhibited by Plantago lanceolata and Trifolium repens. However, at the end of the growing season several seedlings of Trifolim repens appeared as well as Rumex acetosella, which can be presented as an effect of dormancy. Plant species Vicia hirsuta, Rumex acetosella and Agrostis tenuis, followed by Holcus lanatus were successful. However, Vicia hirsuta suffered from increased mortality of seedlings (three weeks post-germination) later in the season. A certain degree of self-thinning after succesful germination of seeds of tested plants, had a positive effect in increasing survival of the remaining individuals to maturity and achieving successful reproduction. Similar observations were made by Dauber etal. (2008), Lenoir (2009), Veen et Olff (2011) and Chen et Li (2012).

Table 5: Degree of germination and survival success of chosen plant seeds sown into the deposit surface area characterised by absence and/or rarity of ant nests, and low plant species diversity.

\begin{tabular}{|l|l|l|l|l|l|l|l|}
\hline & \multicolumn{6}{|l|}{ Number of germinated and survived seeds of 60 in total } \\
\hline $\begin{array}{l}\text { Number of plot/plant } \\
\text { species }\end{array}$ & $\begin{array}{l}\text { Holcus } \\
\text { lanatus }\end{array}$ & $\begin{array}{l}\text { Vicia } \\
\text { hirsuta }\end{array}$ & $\begin{array}{l}\text { Plantago } \\
\text { lanceolata }\end{array}$ & $\begin{array}{l}\text { Rumex } \\
\text { acetosella }\end{array}$ & $\begin{array}{l}\text { Agrostis } \\
\text { tenuis }\end{array}$ & $\begin{array}{l}\text { Trifolium } \\
\text {.repens }\end{array}$ \\
\hline 1 & $4(4)$ & $7(0)$ & 0 & $10(10)$ & $7(6)$ & $1(1)$ \\
\hline 2 & $1(0)$ & $6(6)$ & $3(3)$ & $2(2)$ & $5(4)$ & 0 \\
\hline 3 & $2(0)$ & $4(0)$ & 0 & $1(1)$ & $10(7)$ & 0 \\
\hline 4 & $7(7)$ & $4(1)$ & 0 & $5(5)$ & 0 & $1(1)$ \\
\hline 5 & $5(4)$ & $10(10)$ & 0 & $10(10)$ & $9(7)$ & 0 \\
\hline SUM & $\mathbf{1 9}(\mathbf{1 5})$ & $\mathbf{3 1}(\mathbf{1 6})$ & $\mathbf{3 ( 3 )}$ & $\mathbf{2 8}(\mathbf{2 8})$ & $\mathbf{3 1}(\mathbf{2 4})$ & $\mathbf{2}(\mathbf{2})$ \\
\hline
\end{tabular}

\section{CONCLUSIONS}

- Biodiversity: The results show that species diversity of ants increased moderately (rather, dominant species has changed) and diversity of plants increased several times during one decade.

- Plant-ant relationship: there is a strong dependence of plant species diversity on presence of numerous ant nests.

- Role of myrmecochory: manipulative experiments with plant seed removal (offer of seeds near ant nests) demonstrated plant dispersal. 
- Survival of seedlings established after the ant transport of seeds into ant nests confirmed the role of ants as eco-engineers in restoration.

- Selected parameters of the substrate in abandoned tailings containment show differences among four habitat types (successional stages).

- Extreme soil conditions are balanced in areas inhabited by ants which facilitate the acceleration of vegetation succession.

\section{ACKNOWLEDGEMENTS}

We thank to P. Pech (Dept. Biology, Faculty of Science, University of Hradec Králové) and J. Frouz (Inst. Environment, Faculty of Science, University of Prague) for determinantion of ant species. The work has been supported by the grant no. 206/93/2256 of the Grant Agency of the Czech Republic "Biotic interactions during vegetation succession on toxic substrates", grant no. 200/1997/B/BIO of the Grant Agency of Charles University and by the research project MSM 113100004, chapter "Ecological plasticity and taxonomical variability of expansive plant species" of the Czech Ministry of Education.

\section{REFERENCES}

Agosti, D., Majer, J. D., Alonso, L. E., Schultz, T. R. (eds.) (2000). Ants. Standard methods for measuring and monitoring biodiversity. Smithsonian Institution Press, Washington and London.

Braun-Blanquet, J., (1928). Pflanzensoziologie. - Springer Verlag, Berlin.

Brian, M. V., (1964). Ant pattern and density in southern English heath. Journal of Animal Ecology, 33: pp. 451-461

Brian, M. V., Hibble, J., Stradling, D. J., (1965). Ant pattern and density in southern English heath. Journal of Animal Ecology, 34: pp. 545-555.

Brian, M. V., Elmes, G., Kelly, A. F., (1967). Population of the Tetramorium caespitum Latreille. Journal Animal Ecology, 36: pp. 337-342.

Chen, Y.-W., Li, X.-R., (2012). Spatio-Temporal Distribution of Nests and Influence of Ant (Formica cunicularia Lat.) Activity on Soil Property and Seed Bank after Revegetation in the Tengger Desert. Arid Land Research and Management, 26(4): pp. 365-378.

Czerwinski, Z., Jakubczyk, H., Petal, J., (1971). Influence of ant hills on the meadow soils. Pedobiologia, 11: pp. 277-285.

Culver, D.C., Beattie, A.J., (1983). Effect of ant mounds on soil chemistry and vegetation patterns in a Colorado montane meadow. Ecology, 64: pp. 485-492.

Dauber, J, Niechoj, R, Baltruschat, H et al., (2008). Soil engineering ants increase grass root arbuscular mycorrhizal colonization. Biology and Fertility of Soils, 44(5): pp. 791-796.

Frouz, J., (1996). Ants (Hymenoptera: Formicidae) in dump after brown coal excavations and the surrounding within the Sokolovsko Region. Collect. Distr. Museum, Most, Ser. Nat., 18: pp. 45-51. [in Czech]

Frouz, J., Šantrůčková, H., Kalčík, J., (1997). The effect of wood ants (Formica polyctena Forest.) on the transformation of phosphorus in a spruce plantation. Pedobiologia, 41: pp. 437-447. 
Gorb, E., Gorb, S., (1995). Removal rates of seeds of five myrmecochorous plants by the ant Formica polyctena (Hymenoptera: Formicidae). Oikos 73: pp. 367-374.

Gorb, E., Gorb, S., (2000). Effects of seed aggregation on the removal rates of elaiosomebearing Chelidonium majus and Viola odorata seeds carried by Formica polyctena ants. Ecological Research, 15: pp. 187-192.

Gorb, S., Gorb, E., Sindlarovskaja, Yu., (1997). Interaction between the nonmyrmecochorous herb Galium aparine and the ant Formica polyctena. Plant Ecology, 131: pp. 215-221.

Hölldobler, B., Wilson, E. O., (1990). The Ants. Belknap Press, Cambridge, Massachusetts. Hroudová, Z., Zákravský, P., (2004). The influence of the moss layer on soil surface microclimate in an abandoned ore-washery sedimentation basin. In: Kovář P. (ed.): Natural Recovery of Human-Made Deposits in Landscape (Biotic Interactions and Ore/Ash-Slag Artificial Ecosystems) (pp. 235-247). Academia, Prague

Jarešová, I., Kováŕ, P., (2004). Interactions between ants and plants during vegetation succession in the abandoned ore-washery sedimentation basin in Chvaletice. In: Kovár P. (ed.): Natural Recovery of Human-Made Deposits in Landscape (Biotic Interactions and Ore/Ash-Slag Artificial Ecosystems) (pp. 300-310). Academia, Prague

Jones, C.G., Lawton, J.H., Shachak, M., (1994). Organisms as ecosystem engineers. Oikos, 69: pp. 373-386.

Jouquet, P., Dauber, J., Lagerlof, J., Lavelle, P., Lepage, M., (2006). Soil invertebrates as ecosystem engineers:intended and accidental effects on soil and feedback loops. Applied Soil Ecology, 32: pp. 153-164.

King, T.J. (1981). Ant-hills and grassland history. J. Biogeogr., 8: pp. 329-334.

Kovář, P. (ed.), (2004). Natural Recovery of Human-Made Deposits in Landscape (Biotic Interactions and Ore/Ash-Slag Artificial Ecosystems). Academia, Prague.

Kovář, P., Kovářová, M., (1998). Ant herbivory - a significant factor in population dynamics of Veronica and other temperate plant species? Thaiszia-J.Bot., 8: pp. 141-146.

Kovář, P., Kovářová, M., Dostál, P., Herben, T., (2001). Vegetation of anthills in a mountain grassland: effects of mound history and of dominant ant species. Plant Ecology, 156: pp. 215-227.

Kovář, P., Štefánek, M., Mrázek, J., (2011). Responses of vegetation stages with woody dominants to stress and disturbance during succession of abandoned tailings in cultural landscape. Journal of Landscape Ecology, 4(2): pp. 35-48.

Meysman, F. J. R., Middelburg, J. J., Heip, C. H. R., (2006). Bioturbation: a fresh look at Darwin's last idea. Trends in Ecology \& Evolution, 21(12): pp. 688-695.

Lenoir, L., (2009). Effects of ants on plant diversity in semi-natural grasslands. ArthropodPlant Interactions, 3(3): pp. 163-172.

Pohlová, R., (2004). Changes on microsites of the moss Ceratodon purpureus and lichens Peltigera didactyla and Cladonia sp. div. in the abandoned sedimentation basin in Chvaletice. - In: Kovář P. (ed.): Natural Recovery of Human-Made Deposits in Landscape (Biotic Interactions and Ore/Ash-Slag Artificial Ecosystems) (p. 222-234). Academia, Prague

Rauch, O., (2004). Genesis and characteristics of orewaste sulphate soils at Chvaletice. - In: Kováŕ P. (ed.): Natural Recovery of Human-Made Deposits in Landscape (Biotic Interactions and Ore/Ash-Slag Artificial Ecosystems) (p. 45-58). Academia, Prague 
Sanders, D., van Veen, F. J. F., (2011). Ecosystem engineering and predation: the multitrophic impact of two ant species. Journal of Animal Ecology, 80(3): pp. 569-576.

Štefánek, M., (2004). Secondary succession after fire on an abandoned ore-washery sedimentation basin - different trajectories (A comparison with primary succession). - In: Kovář P. (ed.): Natural Recovery of Human-Made Deposits in Landscape (Biotic Interactions and Ore/Ash-Slag Artificial Ecosystems) (p. 248-266). Academia, Prague

Štefánek, M., Kovář, P., Dlouhá, V., (2012). Role of fire episode,leaf litter decomposition and mulching effects in restoration of the surface soil crust microecosystem on abandoned tailings containment. Journal of Landscape Ecology, 5(3): pp. 57-69.

Vaňková, J., Kováŕ, P., (2004). Plant species diversity in the biotopes of un-reclaimed industrial deposits as artificial islands in landscape. - In: Kovář P. (ed.): Natural Recovery of Human-Made Deposits in Landscape (Biotic Interactions and Ore/Ash-Slag Artificial Ecosystems) (p. 30-45). Academia, Prague

Veen, G. F., Olff, H., (2011). Interactive effects of soil-dwelling ants, ant mounds and simulated grazing on local plant community composition. Basic and Applied Ecology, 12(8): pp. 703-712.

Vlasáková, B., Raabová, J., Kyncl, T., Dostál, P., Kovářová, M., Kovář, P., Herben, T., (2009). Ants speed up succession from grassland towards forest. Journal of Vegetation Science, 20: pp. 577-587.

Vojtíšek, P., (2012). Ants and primary vegetation succession on abandoned industrialwaste deposits. MSc Thesis (deposited in Library of the Institute of Environment, Faculty of Science, Charles University). [in Czech]

Wilson, E. O., (1971). The Insect Societies. Harvard Univ. Press, Cambridge, Massachusetts.

Wolf, A., Debusche, M., (1999). Ants as seed dispersers in Mediterranean old-field succession. Oikos, 84: pp. 443-452.

Wright, J.P, Jones, C.G., (2004). Predicting effects of ecosystem engineers on patch-scale species richness from primary productivity. Ecology, 85: pp.2071-2081. 